\title{
ALIGNMENT BETWEEN THE SUPPLY, MANUFACTURING AND DISTRIBUTION STRATEGIES AND THE BUSINESS STRATEGY
}

\author{
Margareth Rodrigues de Carvalho Borella \\ Universidade de Caxias do Sul \\ mrcborel@ucs.br
}

\author{
Antônio Domingos Padula \\ Universidade Federal do Rio Grande do Sul - UFRGS \\ adpadula@ea.ufrgs.br
}

\begin{abstract}
The study aims to identify the degree of alignment between the supply, manufacturing and distribution practices on the one hand and the generic business strategies suggested by Porter (1996): differentiation, low cost, focus on differentiation and focus on low cost on the other and to obtain some insights into how these relationships influence business performance. The gestalt and profile deviation (Venkatraman, 1989) approaches were used to identify the relationship between practices and the degrees of alignment in the respective strategy groups. When compared to other strategy groups, the group of companies predominantly devoted to the Focus on Low Cost strategy $(49,25 \%)$ was found to have: greater consistency in the development of practices between supply, manufacturing and distribution, a high degree of alignment of most of these practices with that strategy, a greater tendency towards achieving better business performance.
\end{abstract}

Keywords: alignment, manufacturing strategy, supply strategy, distribution strategy

\section{INTRODUCTION}

The value of studies such as the present is increasingly apparent, since industrial companies are constantly introducing new knowledge and new technologies, of both a technical and managerial nature, which often causes internal misalignment between operations (Smaczny, 2001; Wheelwright, 1984). Misalignment is the result of low synergy between the processes, usually due to the difficulty that leaders encounter in clearly communicating the company's strategy to other levels within the company (Hax \& Wilde II, 2001; Luftman, 2000; Papke-Shields \& Malhotra, 2001). The likely effect of this is the development of practices that are disconnected from each other, reproducing flaws and imperfections throughout the production process, which can compromise the achievement of objectives and business goals and consequently performance. Strategic align- ment in this context means that the decisions taken within the dimension of each sub-strategy should be mutually consistent and converge with the overall business strategy (Joshi, Kathruia \& Porth, 2003; Sun \& Hong, 2002).

The aim of this paper is to examine to what extent the supply, manufacturing and distribution practices are being developed in a manner coherent with each other and consistent with business strategy, and also attempt to evaluate the extent to which alignment and performance are related in the study sample.

\section{The Business Strategy and the Supply, Manufactur- ing and Distribution Strategies}

According to Porter (1989), the main competitive advantages that a company can have are low prices or differentiation. Combining them with the com- 
pany's scope of operations, gives rise to four generic strategies - cost leadership, differentiation, focus on low cost and focus on differentiation - which allow the company to achieve above average performance in their respective segment or industrial sector. The hybrid strategy is a real option in companies, mainly in those within industrial supply chains and engaged in world-class manufacturing, which besides being competitive in terms of price also need to be competitive in terms of quality, flexibility, speed and reliability (Harrison, 1998; Hill, 1988). Decisions taken at the level of production and operations strategy in the scope of industrial firms - supply, manufacturing and distribution, are expected to converge with decisions concerning the generic business strategies (Skinner, 1969; 1974; Wheelwright, 1984).

\section{The Manufacturing Strategy}

The manufacturing strategy reflects how a company intends to compete in the market by making internal choices consistent with their competitive priorities of cost, quality, flexibility, reliability and speed of delivery to achieve global success (Hayes \& Wheelwright, 1984; Hill, 1985; Skinner, 1969; Spring \& Boaden, 1997). By setting the priority in a competitive dimension, for example, low cost, production goals and action plans should reflect this particular direction (Kim \& Arnold, 1996; Neely, 1993; Richardson, Taylor \& Gordon, 1985; Schroeder, Scudder \& Elm, 1989). In the present study, these four structural aspects of decision-making (Hayes \& Wheelwright, 1983) are considered attributes and correspond to the variables related to the manufacturing strategy (Chart 1): Constant Capacity, Specialist Facilities, Flexible High Technology and Vertically Integrated Production.

\section{Chart 1: Theoretical and Conceptual References for the Production Strategy Attributes}

\begin{tabular}{|l|l|l|}
\hline $\begin{array}{c}\text { Manufacturing } \\
\text { Strategy } \\
\text { Attributes }\end{array}$ & \multicolumn{1}{|c|}{ Theoretical and Conceptual Approach } & \multicolumn{1}{c|}{ Authors } \\
\hline $\begin{array}{l}\text { Constant } \\
\text { Capacity }\end{array}$ & $\begin{array}{l}\text { Capacity is a key determinant in response time to } \\
\text { customers. The increase in capacity utilization is directly } \\
\text { related to the higher rate of return on capital. }\end{array}$ & $\begin{array}{l}\text { Rajagopalan and Yu (2001); } \\
\text { Wheelwright (1984) }\end{array}$ \\
\hline $\begin{array}{l}\text { Specialist } \\
\text { Facilities }\end{array}$ & $\begin{array}{l}\text { Represents a competitive weapon because its structure is } \\
\text { dedicated to perform a particular production task, arising } \\
\text { from the business strategy and marketing objectives, whose } \\
\text { goal is to serve a niche or particular market segment. }\end{array}$ & $\begin{array}{l}\text { Griffiths and Margetts (2000); Ketokivi } \\
\text { and Jokinen (2006); Skinner (1974); } \\
\text { Van Donk and Van Der Vaart (2007); } \\
\text { Wheelwright (1984) }\end{array}$ \\
\hline $\begin{array}{l}\text { Flexible High } \\
\text { Technology }\end{array}$ & $\begin{array}{l}\text { The result of combining high technology with process } \\
\text { flexibility is to achieve technical accuracy and the ability } \\
\text { to execute different product designs. }\end{array}$ & $\begin{array}{l}\text { Morita and Flynn (1997); O'Regan and } \\
\text { Ghobadian (2005); Ward, McCreery } \\
\text { and Anand (2007) }\end{array}$ \\
\hline $\begin{array}{l}\text { Integrated } \\
\text { Production }\end{array}$ & $\begin{array}{l}\text { Rests on the theories of RBV (Resource Based View) and } \\
\text { for its maintenance are: achieving higher profits, reduced } \\
\text { costs, reduced risk of dependence on other firms and } \\
\text { absence of a qualified supplier. }\end{array}$ & $\begin{array}{l}\text { Ellison (2005); Fine (2000); Hoffmann } \\
\text { and Schaper-Rinkel (2001) }\end{array}$ \\
\hline
\end{tabular}




\section{The Supply Strategy}

The supply strategy involves a set of definitions that depend on the primary decision "make or buy" (De Toni, Nassimbeni \& Tonchia, 1994). Supply-related decisions are still eminently operational in a large number of companies. With the emergence of the supply chain management approach, there was a change of focus in relation to supply activities, which became a strategic area of business performance (Lee, Kwon \& Severance, 2007; Tan, Kannan \& Handfield, 1998; Vaart \& Van Donk, 2006). For the present study, four supply strategy attributes are listed, two related to the interaction with suppliers dimension, Strategic Relationship with Suppliers and Strategic Supplier Selection, and two related to the procurement dimension, Alternative Supply and Traditional Procurement Process (Chart 2).

\section{Chart 2: Theoretical and Conceptual References for the Supply Strategy Attributes}

\begin{tabular}{|l|l|l|}
\hline Supply Strategy Attributes & \multicolumn{1}{|c|}{ Conceptual and Theoretical Approach } & \multicolumn{1}{c|}{ Authors } \\
\hline Strategic Relationship with \\
Suppliers & $\begin{array}{l}\text { Partnerships, strategic alliances, joint ventures } \\
\text { are explicit manifestations of resource sharing, } \\
\text { technology, projects, research, cost savings between } \\
\text { supplier - customer. }\end{array}$ & $\begin{array}{l}\text { Chen, Paulraj and Lado } \\
\text { (2004); Field and Meile } \\
\text { (2008); Fynes and Voss } \\
\text { (2002); Kouvelis, Chambers } \\
\text { and Wang (2006); Paulraj, } \\
\text { Chen and Flynn (2006) }\end{array}$ \\
\hline Strategic Supplier Selection & $\begin{array}{l}\text { Company focused on differentiation, in addition to } \\
\text { technical criteria, trend to value quality and issues } \\
\text { related to reputation, financial stability, honesty, } \\
\text { culture, and confidentiality of key suppliers. }\end{array}$ & $\begin{array}{l}\text { Fierro and Redondo (2008); } \\
\text { Hsu, Kannan, Leong and } \\
\text { Tan (2006); Juha and Pentti, } \\
\text { (2008); Prajogo (2007) }\end{array}$ \\
\hline Alternative Supply & $\begin{array}{l}\text { By having more than one supplier the company } \\
\text { aims to maximize return on investment by reducing } \\
\text { acquisition costs and ensuring its needs are met. }\end{array}$ & $\begin{array}{l}\text { Janda and Seshadri (2001); } \\
\text { Swift (1995) }\end{array}$ \\
\hline \multirow{2}{*}{$\begin{array}{l}\text { Traditional Procurement } \\
\text { Process }\end{array}$} & $\begin{array}{l}\text { This process is usually used with non-strategic } \\
\text { suppliers, in policies involving large inventories, } \\
\text { with long life cycle products and procurement-based } \\
\text { businesses. }\end{array}$ & $\begin{array}{l}\text { Cousins (2005); Gulbrandsen, } \\
\text { Sandvik and Haugland } \\
\text { (2009); Pressey, Winklhofer } \\
\text { and Tzokas (2009) }\end{array}$ \\
\hline
\end{tabular}

\section{The Distribution Strategy}

The distribution strategy involves a number of decisions which are intended to determine how the company will serve the market and customers with its products and services (Pagh \& Cooper, 1998; Stock \& Lambert, 2001; Wanke, 2004). Such decisions must be consistent with the business strategy and the specifications of the client. For this research, four attributes have been listed (Chart 3) for the distribution strategy, two decisions pertaining to the more technical side of logistics - Centralized Distribution and Responsiveness to the Customer, and two belonging to the attitudes-service composite Customer Oriented and Company-Customer Operating Collaboration. 


\section{Chart 3: Theoretical and Conceptual References for the Distribution Strategy Attributes}

\begin{tabular}{|l|l|l|}
\hline \multicolumn{1}{|c|}{$\begin{array}{c}\text { Distribution Strategy } \\
\text { Attributes }\end{array}$} & \multicolumn{1}{|c|}{ Conceptual and Theoretical Approach } & \multicolumn{1}{c|}{ Authors } \\
\hline $\begin{array}{l}\text { Centralized } \\
\text { Distribution }\end{array}$ & $\begin{array}{l}\text { The results of this practice are: shorter and more reliable } \\
\text { lead-times, lower inventory costs, constant transport } \\
\text { costs and the more rapid introduction of new products. }\end{array}$ & $\begin{array}{l}\text { Loomba (1998); Pagh and } \\
\text { Cooper (1998) }\end{array}$ \\
\hline $\begin{array}{l}\text { Responsiveness to the } \\
\text { Customer }\end{array}$ & $\begin{array}{l}\text { It appears as an attribute of the service, being a } \\
\text { component of market or client orientation, which } \\
\text { has been measured using scales like MARKOR, } \\
\text { SERVQUAL and SERVPERF. }\end{array}$ & $\begin{array}{l}\text { Kohli, Jaworski and Kumar } \\
\text { (1993); Parasuraman, } \\
\text { Zeithaml and Berry (1985); } \\
\text { Van Donk and Van Der } \\
\text { Vaart (2007) }\end{array}$ \\
\hline Customer Orientation & $\begin{array}{l}\text { Involves a set of critical actions for company } \\
\text { competitiveness that are intended to support the } \\
\text { client: after-sales service, customized customer service, } \\
\text { distribution logistics, information supplied on request, } \\
\text { review of the delivery schedule, customer satisfaction } \\
\text { assessment. }\end{array}$ & $\begin{array}{l}\text { Blesa and Bigné (2005); Kohli } \\
\text { and Matsuno (1997); Saura, } \\
\text { Francés, Contrí and Blasco } \\
\text { (2008); Tucker (1994) }\end{array}$ \\
\hline $\begin{array}{l}\text { Company-Customer } \\
\text { Operational }\end{array}$ & $\begin{array}{l}\text { This supplier-customer interaction tends to be marked } \\
\text { by: information sharing on demand (quantity, delivery } \\
\text { time and price) and regarding forecasts of demand and } \\
\text { sales, exclusively commercial relationship. }\end{array}$ & $\begin{array}{l}\text { Cousins (2005); Parker and } \\
\text { Anderson Jr. (2002); Ring } \\
\text { and Van De Ven (1992) }\end{array}$ \\
\hline
\end{tabular}

\section{Alignment of Supply, Manufacturing and Distri- bution with the Business Strategy}

Strategic alignment became a focus of study when it was found that companies in which the organizational structures were suitably adjusted to the business strategy performed better than others (Chandler, 1962; Rumelt, 1974). Since then, specific studies have been carried out on the alignment of resources and internal processes with business strategy and competitive advantage (Croteau \& Bergeron, 2001; Decoene \& Bruggeman, 2006; Defee \& Stank, 2005; Edelman, Brush \& Manolova, 2005; Scherpereel, 2006; Sussland, 2003; Venkatraman, 1989).

Figure 1 shows the alignment model that guides the following research question: Does having the supply, manufacturing and distribution practices aligned with each other and with the business strategy lead firms to perform better?

Vertical alignment (Figure 1) is achieved when the supply, manufacturing and distribution substrategies are developed in such a way as to reflect the business strategy (Hax \& Wilde II 2001; Kathuria, Joshi \& Porth, 2007). Horizontal alignment (Figure 1) becomes apparent when the development of a practice within a sub-strategy enables or supports the development of a practice in another sub-strategy, all of which are shaped by a particular business strategy (Venkatraman \& Camillus, 1984). Studies have shown that the greater the horizontal and/or vertical alignment within a company the better it tends to perform in relation to its main competitors (Mcadam \& Bailie, 2002; Sun \& Hong, 2002). 
Figure 1: Alignment in the Research Model

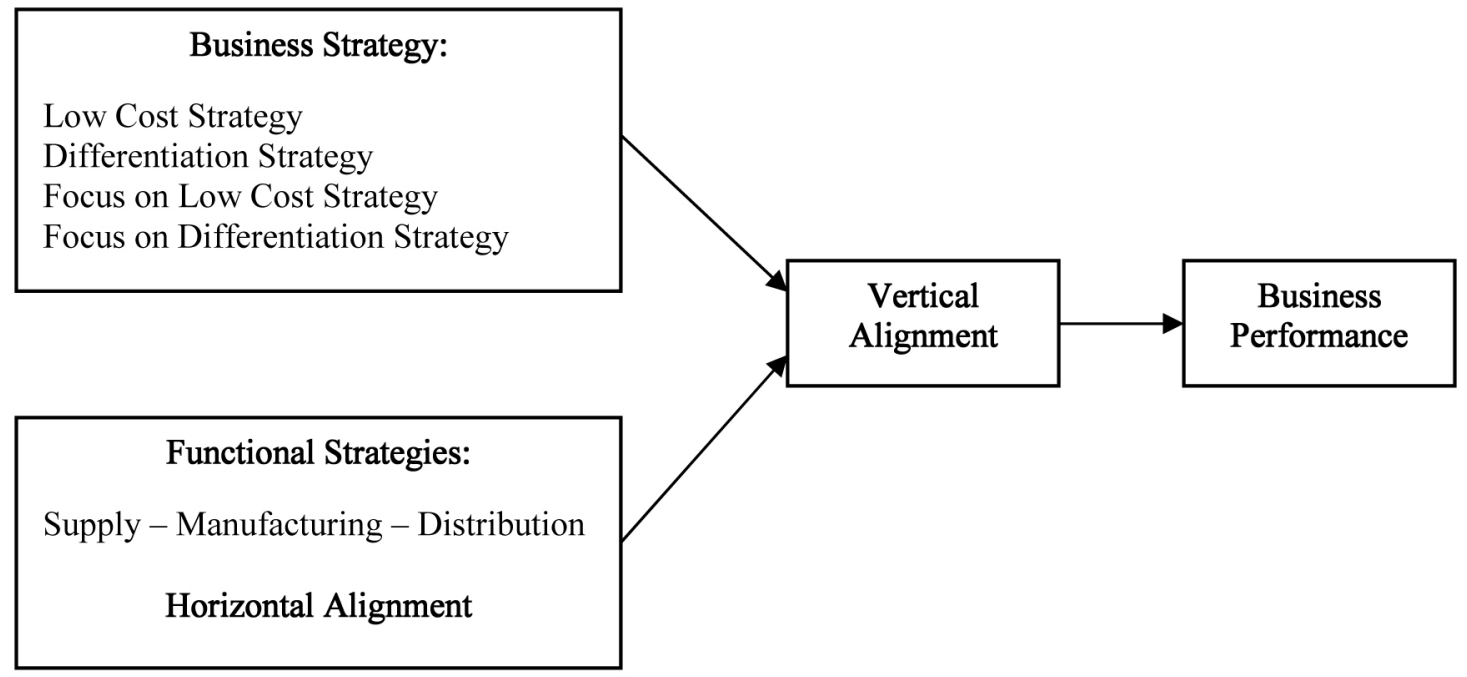

Theoretical Frameworks for the Analysis of Vertical and Horizontal Alignment

The four generic theoretical profiles that define the degree to which each variable in each functional strategy - supply, manufacturing and distribution - should be emphasized by the firms in the context of the four generic business strategies - low cost, differentiation, focus on low cost and focus on differentiation - are presented in Chart 4. These theoretical profiles were constructed based on a review of the literature together with the generic strategies from Porter (1989) and in studies using his typology (Allen \& Helms, 2006; Miller \& Friesen, 1986).

In Chart 4, the "+" sign suggests that the company should give more emphasis to that aspect of supply, manufacturing or distribution, if it is more directed towards that strategy. "Emphasis" means a "heavily biased action" by the company to develop that aspect. The "-" sign suggests that the company should not emphasize this point because it is not theoretically consistent with the scope of the dominant strategy. The symbol " 0 " means that aspect is irrelevant for the development of that strategy.

Chart 4: Theoretical Frameworks of Alignment of Supply, Manufacturing and Distribution with the Generic Business Strategies

\begin{tabular}{|l|c|c|c|c|}
\hline \multirow{2}{*}{$\begin{array}{c}\text { Attributes of } \\
\text { Supply, Manufacturing and Distribution }\end{array}$} & Low Cost & Differentiation & $\begin{array}{c}\text { Focus on } \\
\text { Differentiation }\end{array}$ & $\begin{array}{c}\text { Focus on Low } \\
\text { Cost }\end{array}$ \\
\cline { 2 - 5 } $\begin{array}{c}\text { Supply } \\
\text { 1) Strategic Relationship with Suppliers - (RS) }\end{array}$ & - & + & + & 0 \\
\hline 2) Strategic Selection of Suppliers - (SS) & - & + & + & 0 \\
\hline 3) Alternative Suppliers - (AS) & + & - & 0 & + \\
\hline 4) Traditional Purchasing Process-(TP) & + & - & - & + \\
\hline Manufacturing & + & - & - & + \\
\hline 1) Constant Capacity-(CC) & - & + & + & 0 \\
\hline
\end{tabular}




\begin{tabular}{|l|c|c|c|c|}
\hline 3) Vertically Integrated Production-(VP) & + & - & 0 & + \\
\hline 4) Specialized Facilities - (SF) & - & + & + & + \\
\hline \multicolumn{1}{|c|}{ Distribution } \\
$\begin{array}{l}\text { 1) Centralized Distribution-(CD) } \\
\text { 2) Customer Oriented-(CO) }\end{array}$ & + & - & 0 & + \\
\hline 3) Responsiveness to the Customer-(RC) & - & + & + & + \\
\hline $\begin{array}{l}\text { 4) Company-Customer Operational } \\
\text { Collaboration-(OC) }\end{array}$ & + & - & - & + \\
\hline
\end{tabular}

\section{Research Methodology}

This study is descriptive in nature and culminates in the development of all study employing a survey (Gil, 1999). The survey was conducted among industrial enterprises belonging to the metal-working sector in Caxias do Sul, Brazil. Of the 2,500 companies registered with the SIMECS (Union of Metallurgical, Mechanical and Electrical Material de Caxias do Sul), 500 responded to questions from the questionnaire by telephone. The respondent in each company had to be the company owner, the production manager or the sales/marketing manager.

\section{Scales of the Survey Questionnaire}

The questionnaire used to gather the data consisted of 17 variables-attributes for which scales were used containing multiple measurement items, whose scores were then standardized from 0 to 1 and represented the corresponding variable. Some of the scales are original, some adapted and previously validated, and some were developed from the literature review (Charts 1,2 and 3) and their purpose is to identify the use of strategic practices by companies. For the variables of the business strategy and the attributes of the supply, manufacturing and distribution, the original scales used to collect data were interval of intensity ranging from 1 to 5 where $1=$ totally disagree and $5=$ totally agree. For the variables of business performance, a scale was used in order to measure the comparative performance of the interviewed company in relation to its major competitors, where $1=$ much worse than competitors and $5=$ much better than the competitors.

\section{Validation of the Scales in the Survey Questionnaire}

The Content validity or expression is meant to subjectively evaluate the degree to which the questions are understood (Hair, Anderson, Tatham \& Black,
2005). To meet this requirement two verbal comprehension pre-tests were carried out with the first version of the questionnaire. Two university professors, one a PhD in Production Engineering and the other a PhD in Administration were involved. Some measuring items were replaced and others were eliminated because they failed to meet the required orthogonality of the remaining items in the same variable.

The unidimensionality of multiple scales for each of the 17 variables and internal reliability of the questionnaire were analyzed using two statistical tests involving pre-exploratory factor analysis with the principal components extraction method. Unidimensionality assumes that the items of the same scale or variable should be strongly associated with each other and represent a single concept (Hair et al., 2005; Malhotra, 2001). The reliability of the scale was assessed using Cronbach's Alpha (Hair et al., 2005). The first statistical pre-test was conducted with 40 students attending an MBA course in Production Strategy. The second statistical pre-test was conducted with 50 companies from within the study population.

\section{Calculating the Alignment in the Research Model}

Two approaches from Venkatraman (1989) were used to analyze the alignment in the research: Gestalt and the Profile Deviation in relation to the Theoretical Profile. In the Gestalt perspective, the horizontal alignment was evaluated through analysis of the correlation between the attributes-variables of the supply, manufacturing and distribution functional strategies in the specific context of each business strategy while taking into account the constructed Theoretical Profiles (Chart 4).

In the Profile Deviation Perspective, the misalignment or Euclidean distance is obtained from the 
square root of the square of the difference between the score of each variable of the interviewed company for the attributes of the supply, manufacturing and distribution in the context of its dominant business strategy and the ideal theoretical values. The "+" and "-" signs and the symbol " 0 " that appear in Chart 4 assume, in the misalignment formula, the following numeric values: $(+)=1 ;(0)=0.5,(-)=$ 0 . The rate of alignment is obtained by subtracting the score of the theoretical maximum misalignment with that business strategy and the score of misalignment obtained in each respondent company in relation to that same business strategy (Kathuria et al., 2007; Sabherwal \& Chan, 2001):

Alignment in each company $=($ Score for the maximum theoretical misalignment) - (Score for the misalignment obtained in each company).

The alignment score is sensitive to the scale used, so the values of the variables were standardized so as to vary in a range from 0 to 1 . The misalignment formulas corresponding to the theoretical profiles of the four business strategies presented in Chart 4 are described in the following formulas (1) to (4).

Misalignment in the context of the Low Cost (LC) Business Strategy:

supply attributes

manufacturing attributes

(1) $M_{(L C)}=\operatorname{root}\left\{\left[\left(\mathrm{X}_{R S}-0\right)^{2}+\left(\mathrm{X}_{S S}-0\right)^{2}+\left(\mathrm{X}_{A S}-1\right)^{2}+\left(\mathrm{X}_{T C}-1\right)^{2}\right]+\left[\left(\mathrm{X}_{C C}-1\right)^{2}+\left(\mathrm{X}_{F T}-0\right)^{2}+\left(\mathrm{X}_{V P}-1\right)^{2}+\left(\mathrm{X}_{S F}-0\right)^{2}\right]+\right.$

$$
\underbrace{\left[\left(\mathrm{X}_{C D}-1\right)^{2}+\left(\mathrm{X}_{C O}-0\right)^{2}+\left(\mathrm{X}_{R C}-0\right)^{2}+\left(\mathrm{X}_{O C} 1\right)^{2}\right]}_{\text {distribution attributes }}
$$

Misalignment in the context of the Differential $(D)$ Business Strategy:

$$
\begin{gathered}
\text { (2) } M_{(D)}=\operatorname{root}\{\underbrace{\text { supply attributes }}_{\text {distribution attributes }}+\underbrace{\left.\left[\left(\mathrm{X}_{R S}-1\right)^{2}+\left(\mathrm{X}_{C C}-0\right)^{2}+1\right)^{2}+\left(\mathrm{X}_{A S}-0\right)^{2}+\left(\mathrm{X}_{C P}-0\right)^{2}\right]+\left[\left(\mathrm{X}_{C C}-0\right)^{2}+\left(\mathrm{X}_{F T}-1\right)^{2}+\left(\mathrm{X}_{V P}-0\right)^{2}+\left(\mathrm{X}_{S F}-1\right)^{2}\right]+}
\end{gathered}
$$

Misalignment in the context of the Focus on Differentiation (FD) Business Strategy:

$$
\text { supply attributes manufacturing attributes }
$$

(3) $M_{(F D)}=\operatorname{root}\left\{\left[\left(\mathrm{X}_{R S}-1\right)^{2}+\left(\mathrm{X}_{S S}-1\right)^{2}+\left(\mathrm{X}_{A S}-0,5\right)^{2}+\left(\mathrm{X}_{T P}-0\right)^{2}\right]+\left[\left(\mathrm{X}_{C C}-0,5\right)^{2}+\left(\mathrm{X}_{F T}-1\right)^{2}+\left(\mathrm{X}_{V P}-0,5\right)^{2}+\left(\mathrm{X}_{S F}-1\right)^{2}\right.\right.$

$\left.+\left[\left(\mathrm{X}_{C D}-0,5\right)^{2}+\left(\mathrm{X}_{C O}-1\right)^{2}+\left(\mathrm{X}_{R C}-1\right)^{2}+\left(\mathrm{X}_{O C}-0\right)^{2}\right]\right\}$

distribution attributes

Misalignment in the context of the Focus on Low Cost (FC) Business Strategy:

supply attributes manufacturing attributes

(4) $M_{(F C)}=\operatorname{root}\left\{\left[\left(\mathrm{X}_{R S}-0,5\right)^{2}+\left(\mathrm{X}_{S S}-0,5\right)^{2}+\left(\mathrm{X}_{A S}-1\right)^{2}+\left(\mathrm{X}_{T P}-1\right)^{2}\right]+\left[\left(\mathrm{X}_{C C}-1\right)^{2}+\left(\mathrm{X}_{F T}-0,5\right)^{2}+\left(\mathrm{X}_{V P}-1\right)^{2}+\left(\mathrm{X}_{S F}-\right.\right.\right.$

1) $\left.{ }^{2}\right]+$

$$
\underbrace{+\left[\left(\mathrm{X}_{C D}-1\right)^{2}+\left(\mathrm{X}_{C O}-1\right)^{2}+\left(\mathrm{X}_{R C}-1\right)^{2}+\left(\mathrm{X}_{O C}-1\right)^{2}\right]}_{\text {distribution attributes }}\}
$$


In order for all the alignment scores in each respondent company to also vary from 0 to 1 , the formulas used to calculate the alignment within the context of each business strategy are presented in sequence from (5) to (8).

For the Low Cost Strategy in formula (1), by replacing each variable with maximum values that contrast to the theoretical value in each term of the formula, the theoretical maximum misalignment for the Low Cost Strategy equals 3.46, then, formula (5) for the alignment of each respondent company with the Low Cost Strategy is equal to:

(5) $A_{(L C)}=1-\left(M_{(L C)}\right.$ obtained in each company / 3.46)

The formulas for the calculation of alignment with other Business Strategies, by similarity, are presented in (6) (8).

Alignment in the context of the Differentiation Business Strategy $(D)$ :

(6) $\quad A_{(D)}=1-\left(M_{(D)}\right.$ obtained in each company / 3.46)

Alignment in the context of the Focus on Differentiation Business Strategy $(F D)$ :

(7) $A_{(F D)}=1-\left(M_{(F D)}\right.$ obtained in each company / 3)

Alignment in the context of the Focus on Low Cost Business Strategy $(F C)$ :

$$
A_{(F C)}=1-\left(M_{(F C)}\right. \text { obtained in each company / 3.12) }
$$

\section{The Research Model Variables}

The standardized scores of the variable Business Performance represented the dependent variable in the analysis of the vertical alignment (Figure 1) and the standardized scores of the vertical alignments with their respective business strategies - $A_{(L C)^{\prime}} A_{(D)^{\prime}}$ $A_{(F D)^{\prime}} A_{(F C)^{\prime}}$ represented the independent variables. The standardized scores of the original variables (Table 2), the attributes of Supply Strategy, Production Strategy and Distribution Strategy, were also used in order to be interrelated in the analysis of the horizontal alignments.

Statistical Techniques employed in the Analysis of the Research Model

Exploratory factor analysis was used together with Cronbach's alpha to confirm the validity of the scales of the variables and the questionnaire in the field research. Pearson's method of bi-variate correlation was used in the analysis of the horizontal alignments (Gestalt) in which the variables-attributes of the Supply, Production and Distribution and Strategies were related to each other. Multiple Linear Regression was used to establish the relationship among the supply, manufacturing and distribution attributes, and the dependent variable, business strategy.

\section{Results}

\section{Final Sample}

When sifting the data, cases in which all the items of a variable remained unanswered were excluded, thus negating the variable, likewise in cases with marking problems and bias in the responses. There was no confirmation of outlier cases. The final sample $(N)$ consisted of 400 cases and was shown to be representative of the study population (Table 1), since the metal-working sector is previously characterized by a significant predominance of small businesses (SEBRAE, 1999), formed in supply chains and belonging to the metallurgical sub-sector.

Table 1 - Characteristics of the Metal-working Companies

\begin{tabular}{cccc}
\hline Nr. Of Employees & Size of the companies & Frequency & \% \\
\hline 2 a 19 & Micro & 277 & 69.25 \\
20 a 99 & Small & 83 & 20.75 \\
100 -500 & Medium & 13 & 3.25 \\
Over 500 & Large & 4 & 1.00 \\
Total & - & $\mathbf{4 0 0}$ & $\mathbf{1 0 0}$ \\
\hline \multicolumn{2}{c}{ Industrial Subsector } & Frequency & $\mathbf{\%}$ \\
\hline Metallurgical Industry & 327 & 81.8 \\
Mechanical Industry & 57 & 14.3 \\
Electrical material and communications & 10 & 2.5 \\
Transport Material & 6 & 6 & 1.5 \\
& Total & $\mathbf{4 0 0}$ & $\mathbf{1 0 0}$ \\
\hline
\end{tabular}




\begin{tabular}{lcc}
\hline \multicolumn{1}{c}{ Types of Customers } & Frequency & \% \\
\hline Other industrial firms & 271 & 67.8 \\
Trade or service firms & 83 & 20.8 \\
Consumer or individual end user & 46 & 11.4 \\
$\quad$ Total & $\mathbf{4 0 0}$ & $\mathbf{1 0 0}$ \\
\hline
\end{tabular}

Validation of the Scales in the Study Sample

In Table 2, it can be seen that, with the exception of "Focus on Differentiation Strategy" all the other variables had Cronbach's alpha scores greater than 0.600 , meaning that the items measuring the multiple scales of the variables are sufficiently interrelated to represent such variables. Some variables are also shown to have an explanatory power below
$50 \%$, which is the pre-set minimum percentage for the explained variance of each variable. Since none was below $40 \%$, the analysis involving these variables must be carefully examined. The KMO index of all the variables was above 0.600 , which is the minimum acceptable value for adequacy of the factor analysis because the study is descriptive in character (Hair et al., 2005; Malhotra, 2001).

Table 2 - Unidimensionality and Reliability of the Scales in the Study Sample

\begin{tabular}{llccc}
\hline \multicolumn{1}{c}{ Variables of the research model } & $\begin{array}{c}\text { Cronbach's } \\
\text { alpha }\end{array}$ & Eigenvalue & $\begin{array}{c}\text { Explained } \\
\text { variance (\%) }\end{array}$ & KMO \\
\hline I) Attributes of the Business Strategy & & & & \\
1) Differentiation Strategy & 0.834 & 3.300 & 55.00 & 0.810 \\
2) Low Cost Strategy & 0.700 & 2.284 & 45.68 & 0.737 \\
3) Focus on Differentiation Strategy & 0.599 & 1.669 & 41.73 & 0.604 \\
4) Focus on Low Cost Strategy & 0.687 & 2.287 & 45.75 & 0.734 \\
\hline II) Attributes of the Manufacturing Strategy & & & & \\
5) Constant Capacity & 0.710 & 2.334 & 46.68 & 0.737 \\
6)Flexible High Technology & 0.823 & 2.966 & 59.31 & 0.831 \\
7) Vertically Integrated Production & 0.727 & 2.411 & 48.21 & 0.724 \\
8)Specialized Facilities & 0.851 & 3.172 & 63.43 & 0.809 \\
\hline III) Attributes of the Supply Strategy & & & & \\
9)Strategic Relationship with Suppliers & 0.826 & 2.975 & 59.49 & 0.808 \\
10)Strategic Selection of Suppliers & 0.832 & 3.006 & 60.11 & 0.852 \\
11)Alternative Suppliers & 0.781 & 2.673 & 53.46 & 0.802 \\
12) Traditional Purchasing Process & 0.688 & 2.280 & 45.60 & 0.763 \\
\hline IV) Attributes of the Distribution Strategy & & & & \\
13)Centralized Distribution & & & & \\
14)Customer Oriented & 0.902 & 3.610 & 72.20 & 0.874 \\
15)Responsiveness to the Customer & 0.837 & 3.098 & 61.95 & 0.849 \\
16) Company-Customer Operational & 0.852 & 3.171 & 63.41 & 0.862 \\
Collaboration & 0.832 & 3.002 & 60.04 & 0.817 \\
\hline
\end{tabular}


V) Company Performance Measures

17) Business Performance

0.893

Net Profit in 2008

Gross Sales Revenue in 2008

Productivity in 2008

Sales Growth in 2008

Market Share in 2008

$N=400$ valid cases. The overall Cronbach's alpha for the questionnaire is 0.93 .

Assumption Inherent to the Multivariate Statistical Analysis

Analyses of the statistical assumptions of data normality, linearity between dependent and independent variables, equal variance over the entire domain of the independent variable, low multicollinearity among independent variables (Hair et al., 2005) were conducted with the scores for the variables previously standardized from 0 to 1 .

Classification of the companies according to the dominant business strategy
The highest standardized score obtained from among the four variables of strategy was defined as the business strategy of each company. Five classes of business strategy were stratified in the study sample. Class 5 was formed by companies with scores tied in two or more business strategies (Figure 2). In more than $80 \%$ of the companies participating in the research the predominant business strategy was found to be that of low cost $(L C)$, Classes 1 and 2.

Figure 2: Descriptive Analysis of the Companies classified according to Business Strategies

\begin{tabular}{|c|c|}
\hline Class 1 & Class 2 \\
\hline Low Cost Strategy (LC) & Focus on Low Cost Strategy (FC) \\
\hline 130 companies & 197 companies \\
\hline $82.3 \%$ belong to the Metallurgical Industry & $82.2 \%$ belong to the Metallurgical Industry \\
\hline $69.2 \%$ have other industrial companies as clients & $66.5 \%$ have other industrial companies as clients \\
\hline $60.8 \%$ have up to 10 employees & $64.5 \%$ have up to 10 employees \\
\hline $3.2 \%$ have between 100 to 500 employees & $3.5 \%$ have 100 to 2300 employees \\
\hline Class 3 & Class 4 \\
\hline Focus on Differentiation Strategy (FD) & Differentiation Strategy (D) \\
\hline 53 companies & 5 companies \\
\hline $83 \%$ belong to the Metallurgical Industry & $80 \%$ belong to the Metallurgical Industry \\
\hline $71.7 \%$ have other industrial companies as clients & $60 \%$ have other industrial companies as clients \\
\hline $56.6 \%$ have up to 10 employees & $40 \%$ have up to 12 employees \\
\hline $3.8 \%$ have 150 to 400 employees & $20 \%$ have 2000 employees \\
\hline
\end{tabular}




\begin{tabular}{|c|}
\hline Class 5 \\
More than one Strategy \\
15 companies \\
$66.7 \%$ belong to the Metallurgical Industry \\
$60 \%$ have other industrial companies as clients \\
$60 \%$ have up to 10 employees \\
$20.1 \%$ have 90 to 170 employees
\end{tabular}

Horizontal Alignment in the Classes of Business Strategies

The internal consistency between the strategic supply, manufacturing and distribution practices (dyadic relationships) was assessed in accordance with the Gestalt perspective (Venkatraman, 1989) through bivariate correlation analysis (Figure 3) between the respective original variables.

In this analysis, only the relationships that correlated $>0.300$ with a significance level of 0.05 and mutually consistent according to theoretical profile were presented. Based on the results in Figure 3, Class 3, corresponding to companies classified in the Focus on Differentiation Strategy presented the largest number of consistent relationships.

It is worth mentioning that no theoretical profile was developed beforehand for Class 5, More Than One Business Strategy, due to the difficulty of faithfully representing ambiguous practices. Thus, it was not possible to obtain consistent relations in this class of strategy. Class 4, Differentiation Strategy, shows the highest correlations between practices. Such correlations should be interpreted with caution due to the insufficiency of the sample size. In Figure 3, there is a trend for the relations between practices to be more present in the Supply - Distribution dyad than in the other two dyads, Supply - Production and Production - Distribution.

\section{Vertical Alignment and Business Strategy Relationship}

To check the internal consistency of the practices with the prevailing business strategy, linear regression was performed, in which the dependent variable is the business strategy and the independent variables are the functional practices of the supply, manufacturing and distribution strategies.

According to Table 3, the variables or attributes Flexible High Technology (FT), Strategic Selection of Suppliers (SS) and Responsiveness to the Customer (RC) were able to explain $39.8 \%$ in the dependent variable of Focus on Low Cost Strategy. However, only the variable-attribute Responsiveness to the Customer ( $R C$ ) is consistent with the theoretical profile of Focus on Low Cost Strategy of Chart 4, and is also the biggest contributor to the overall model Focus on Low Cost Strategy, with a linear combination coefficient of 0.404 . The linear regression model for the dependent variable Focus on Differentiation Strategy (Table 3) can be explained in $60.9 \%$ by the variables-attributes, Vertically Integrated Production (VP), Responsiveness to the Customer (RC) and Customer Oriented (CO). The attribute Responsiveness to the Customer (RC) is also the most significant for the development of the Focus on Differentiation Strategy, since its linear combination coefficient has the highest value in relation to other variables in the model, $\Leftarrow=0.456$. Only the Responsiveness to the Customer (RC) and Customer Oriented (CO) achieve this internal consistency with this strategy. 
Figure 3: Correlations in the functional dyads within the classes of Business Strategy

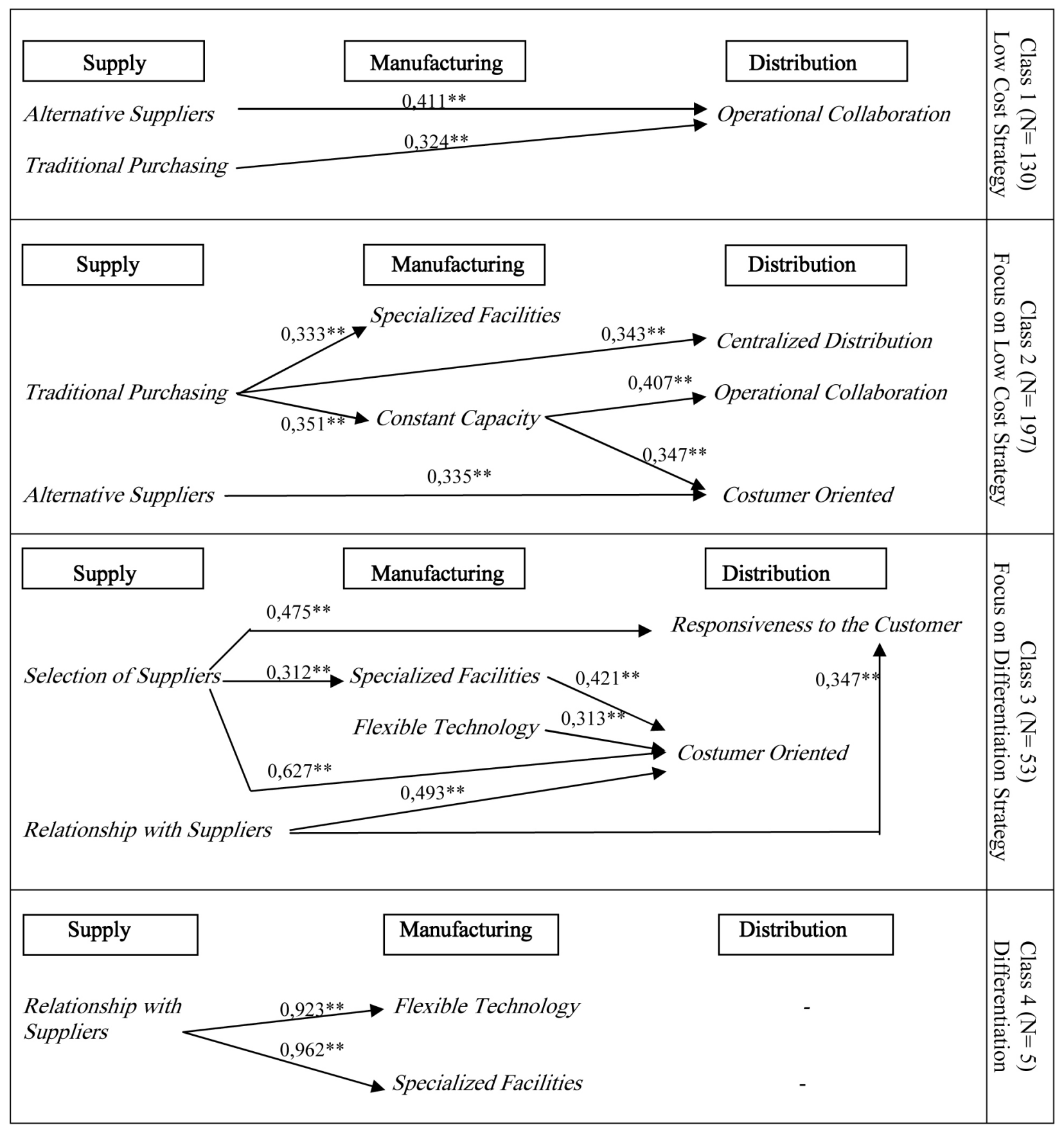

Pearson's Correlation. ${ }^{*}$ Significance at 0.01 two-tailed. Linear regression by the Enter method.

In Class 1, the Low Cost Strategy, the regression model had a low percentage of explanatory power $(9.3 \%)$ by the only significant variable, Flexible High Technology (FT) which is not consistent with the theoretical profile of the Low Cost Strategy.

For Class 4, Differentiation Strategy, it was not possible to obtain a regression equation, due to the lack of cases in the sample. For Class 5, More Than One Business Strategy, the standardized score of each strategy (LC, FC, D, $F D$ ) was taken, one at a time as the dependent variable in linear regression analysis, and none of the attributes of the supply, manufacturing and distribution were found to have a linear combination coefficient with a minimum significance of 0.05 with any business strategy. 
Statistical analysis according to the required parameters for significance and representativeness of the samples showed a tendency of the companies that are predominantly directed towards the Focus on Differentiation Strategy and Focus on Low Cost Strategy to have higher internal consistency between the supply, distribution and manufacturing practices and greater consistency among some internal practices for the development of the respective strategies.

Table 3: Multiple Linear Regressions for the evaluation of the Vertical Alignment

\begin{tabular}{|c|c|c|c|c|c|c|c|}
\hline $\begin{array}{c}\text { Classes of Business } \\
\text { Strategy }\end{array}$ & Dependent Variable & $R$ & $R^{2}$ & $\boldsymbol{F}$ & Sig. of $F$ & b Coefficients & Sig. of $b$ \\
\hline $\begin{array}{c}\text { Class } 1-\text { Low Cost } \\
\qquad N=130\end{array}$ & $\begin{array}{l}\text { Score of the Low } \\
\text { Cost Strategy }\end{array}$ & 0.305 & 0.093 & 13.133 & 0.000 & $\begin{array}{c}\text { Const }=0.764 \\
F T-0.161\end{array}$ & $\begin{array}{l}0.000 \\
0.000\end{array}$ \\
\hline $\begin{array}{l}\text { Class } 2- \\
\text { Focus on Low Cost } \\
\qquad N=197\end{array}$ & $\begin{array}{c}\text { Score of the Focus } \\
\text { on Low Cost } \\
\text { Strategy }\end{array}$ & 0.631 & 0.398 & 42.513 & 0.000 & $\begin{array}{c}\text { Const }=0.357 \\
F T-0.107 \\
S S-0.108 \\
\underline{\boldsymbol{R} C-\mathbf{0 . 4 0 4}}\end{array}$ & $\begin{array}{l}0.000 \\
0.000 \\
0.004 \\
0.000\end{array}$ \\
\hline $\begin{array}{l}\text { Class } 3 \text { - Focus on } \\
\text { Differentiation } \\
\quad N=53\end{array}$ & $\begin{array}{c}\text { Score of the Focus } \\
\text { on Differentiation } \\
\text { Strategy }\end{array}$ & 0.780 & 0.609 & 25.395 & 0.000 & $\begin{array}{c}\text { Const }=0.104 \\
V P-0.243 \\
\underline{R C-\mathbf{0 . 4 5 6}} \\
\underline{\boldsymbol{C O}-\mathbf{0 . 1 8 3}}\end{array}$ & $\begin{array}{l}0.250 \\
0.000 \\
0.000 \\
0.034\end{array}$ \\
\hline
\end{tabular}

\section{Class $4 *_{-}$}

Differentiation

$N=5$

Linear Regression by the Enter Method.

Standardized scores from 0 to 1 were used for all the independent and dependent variables.

*Multiple linear regressions were not performed due to the insufficient sample size.

- Variables of the model that are consistent with the theoretical profile constructed for this strategy (Chart 4).

\section{Alignment versus Business Performance}

The key question is to see which alignments with the theoretical profiles of the business strategies are related to business performance (Figure 1). This analysis was conducted using bivariate correlation with Pearson's correlation coefficient and a significance limit of 0.05 (Table 4 ) between the independent vari- able, the alignment with business strategies $\left(A_{(L C)} A\right.$ $\left.{ }_{(F C)} A_{(D)}, A_{(F D)}\right)$ in the total sample and the stratified samples of class of strategy (Figure 2), and the dependent variable of the research model, the business performance. The business performance matched the standardized score of the sub-variables profitability, gross sales revenue, productivity, sales growth and market share.

Table 4: Correlation of the Alignment with the Strategies and the Business Performance

\begin{tabular}{cccc}
\hline $\begin{array}{c}\text { Class of Business } \\
\text { Strategy }\end{array}$ & Related Variables & $\begin{array}{c}\text { Pearson's Correlation } \\
\text { Coefficient }\end{array}$ & $\begin{array}{c}\text { Significance } \\
\text { two-tailed }\end{array}$ \\
\hline \multirow{2}{*}{ Global Sample } & $A_{(L C)}$ and Performance & -0.060 & 0.230 \\
$N=400$ & $A_{(F C)}$ and Performance & $\underline{\mathbf{0 . 2 5 1}}$ & $\underline{\mathbf{0 . 0 0 0}}$ \\
& $A_{(F D)}$ and Performance & -0.062 & 0.215 \\
& $A_{(D)}$ and Performance & $\underline{\mathbf{0 . 2 3 5}}$ & $\underline{\mathbf{0 . 0 0 0}}$ \\
\hline
\end{tabular}




\begin{tabular}{cccc}
\hline $\begin{array}{c}\text { Class } 1-\text { Low Cost } \\
N=130\end{array}$ & $A_{(L C)}$ and Performance & -0.113 & 0.202 \\
\hline $\begin{array}{c}\text { Class } 2- \\
\text { Focus on Low Cost } \\
N=197\end{array}$ & $A_{(F C)}$ and Performance & $\underline{\mathbf{0 . 2 1 8}}$ & $\underline{\mathbf{0 . 0 0 2}}$ \\
\hline $\begin{array}{c}\text { Class 3 - Focus on } \\
\text { Differentiation } \\
N=53\end{array}$ & $A_{(F D)}$ and Performance & -0.201 & 0.149 \\
\hline $\begin{array}{c}\text { Class } 4-\text { Differentiation } \\
N=5\end{array}$ & $A_{(D)}$ and Performance & 0.407 & 0.497 \\
\hline
\end{tabular}

Scores standardized from 0 to 1.

The results in Table 4 revealed a trend towards improved performance with the increase in the alignment of supply, manufacturing and distribution with the Focus on Low Cost Strategy. A significant correlation at the 0.05 level between alignment and the Differentiation Strategy in the global sample was not confirmed in the stratified sample of the same strategy. The insufficient sample size constitutes a limitation to the results with this strategy.

\section{DISCUSSION OF THE RESULTS}

Upon analyzing the results, based on the theoretical profiles constructed for each business strategy, it was found that few of the supply, manufacturing and distribution practices contained in this research showed a significant relationship ( $\mathrm{p} \leq 0.05)$ with each other with a correlation above 0.500 (Figure 3 ). This correlation would provide greater reliability in order to assert that a particular practice, when developed in a functional strategy allows the development of another practice in another functional strategy. Functional practices with significant correlations with each other are present in Classes of Low Cost, and Focus on Differentiation Strategies (Figure 3).

The linear regression (Table 3) indicated that the Strategic Selection of Suppliers (SS) practice in supply, the Flexible High Technology (FT) in manufacturing and Responsiveness to the Customer (RC) in distribution had an explanatory power of almost $40 \%$ in the Focus on Low Cost Strategy. Likewise, the Vertically Integrated Production (VP) practice in manufacturing, Responsiveness to the Customer (CR) and Customer Oriented (CO) in distribution explained $60.9 \%$ in the Focus on Differentiation Strategy. Responsiveness to the Customer $(R C)$ emerged as a common practice which contributes to reaching targets both in the low cost and differentiation strategies. By the way, only in the alignment of the supply, manufacturing and distribution with Focus on Low Cost Strategy there was trend to obtain better performance.

\section{FINAL REMARKS}

Whereas firms rarely adopt a pure strategy, the results revealed that of the 400 companies in the sample, $96.25 \%$ (385 cases) had a dominant Business Strategy, and in the remaining 3.75\% (15 cases) there was no single predominant strategy, but the coexistence of two or more strategies developed by the respective companies. In most firms $(81.75 \%)$ the actions were predominantly directed towards cost, $32.5 \%$ for Low Cost and $49.25 \%$ for the Focus on Low Cost. Most of these companies, as well as other members of the other classes of business strategy within the metallurgical industry sub-sector, have up to 10 employees and other industrial companies as their main customers (Figure 2). These results corroborate a particular feature of this population - most companies in the metal-working sector in Caxias do Sul are members of large supply chains.

\section{LIMITATIONS OF THE STUDY}

The indices involving the alignment are dependent on the theoretical profiles constructed for the Business of Low Cost, Focus on Low Cost, Differentiation and Focus on Differentiation Strategies. Given the subjectivity involved when considering the emphasis attributed to the use of each practice in each Business Strategy (the "+", "-", "0" in Chart 4) and the risk of researcher bias in interpreting the approaches relat- 
ing to business and functional strategies, there may be failures in the preparation of profiles and consequently the theoretical calculations of alignment.

The sample proved to be representative of the industry and significant in relation to the size, 400 cases, equivalent to $16 \%$ of the study population and yet, the analyses of the results are valid for all the studied companies.

\section{BIBLIOGRAPHICAL REFERENCES}

Allen, R. S. \& Helms, M. M. (2006). Linking strategic practices and organizational performance to Porter's generic strategies. Business Process Management Journal, 12 (4), 433-454.

Blesa, A. \& Bigné, E. (2005). The effect of market orientation on dependence and satisfaction in dyadic relationships. Marketing Intelligence \& Planning, 23 (3), 249-255.

Chandler, A. D. Jr. (1962). Strategy and Structure. The MIT Press, Cambridge, MA.

Chen, I. J.; Paulraj, A. \& Lado, A. A. (2004). Strategic purchasing, supply management and firm performance. Journal of Operations Management, 22, 505-523.

Croteau, A. M. \& Bergeron, F. (2001). An information technology triology: business strategy, technological deployment and organizational performance. Journal of Strategic Information Systems, 10, 77 - 99 .

Decoene, V. \& Bruggeman, W. (2006). Strategic alignment and middle-level managers' motivation in a balanced scorecard setting. International Journal of Operations \& Production Management, 26 (4), $429-448$.

Defee, C. C. \& Stank, T. P. (2005). Applying the strategy-structureperformance paradigm to the supply chain environment. The International Journal of Logistics Management, 16 (1), 28 - 50.

De Toni, A.; Nassimbeni, G. \& Tonchia, S. (1994). New Trends in the Supply Environment. Logistics Information Management, 7 (4), 41-50.

Edelman, L. F.; Brush, C. G. \& Manolova, T. (2005). Co-alignment in the resource-performance relationship: strategy as mediator. Journal of Business Venturing, 20, 359 - 383.

Field, J. M. \& Meile, L. C. (2008). Supplier relations and supply chain performance in financial services processes. International Journal of Operations E Production Management, 28 (2), $185-206$.

Fierro, J. J. C. \& Redondo, Y. P. (2008). Creating satisfaction in the demand-supply chain: the buyers' perspective. Supply Chain Management: An International Journal,13 (3), 211 - 224.

Fine, C. H. (2000). Clockspeed-based strategies for supply chain design. Production and Operations Management, 9 (issue 3), 213 - 222.

Fynes, B. \& Voss, C. (2002). The moderating effect of buyer-supplier relationships on quality practices and performance. International Journal of Operations \& Production Management, 22 (6), $589-613$.
GIL, A. C. (1999). Métodos e Técnicas de Pesquisa Social. Brasil, São Paulo: Atlas.

Griffiths, J. \& Margetts, D. (2000). Variation in production schedules - implications for both the company and its suppliers. Journal of Materials Processing Technology, 103, 155 - 159.

Gulbrandsen, B.; Sandvik, K. \& Haugland, S. A. (2009). Antecedents of vertical integration: Transaction cost economics and resource-based explanations. Journal of Purchasing $\mathcal{E}$ Supply Management, 15, 89 - 102.

Hair, J. F. Jr; Anderson, R.E.; Tatham, R.L. \& Black, W.C. (2005). Análise Multivariada de Dados. $5^{\text {a }}$ ed., Brasil, Porto Alegre: Bookman.

Harrison, A. (1998). Manufacturing strategy and the concept of world class manufacturing. International Journal of Operations E Production Management,18 (4), 397 - 408.

Hax, A. C. \& Wilde II, D. L. (2001). The Delta Project. New York: Palgrave.

Hayes, R. H. \& Wheelwright, S. C. (1984). Restoring Our Competitive Edge. New York: Collier Macmillan.

Hayes, R. H. \& Wheelwright, S. C. (1983). Competing Through Manufacturing. Wiley, New York.

Hill, C. W. L. (1988). Differentiation versus low cost or differentiation and low cost: a contingency framework. Academy of Management Review, 13 (3), $401-412$.

Hill, T. (1985). Manufacturing Strategy. Macmillan, Basingstoke.

Hoffmann, W. H. \& Schaper-Rinkel, W. (2001). Acquire or Ally? A Strategy Framework for Deciding Between Acquisition and Cooperation. Management International Review, 41, 131- 159.

Hsu, C.C.; Kannan, V. R.; Leong, G. K. \& Tan, K.C. (2006). Supplier selection construct: instrument development and validation. The International Journal of Logistics Management, 17 (2), $213-239$.

Janda, S. \& Seshadri, S. (2001). The influence of purchasing strategies on performance. Journal of Business $\mathcal{E}$ Industrial Marketing, 16 (4), $294-308$.

Joshi, M. P.; Kathuria, R. \& Porth, S. J. (2003). Alignment of strategic priorities and performance: an integration of operations and strategic management perspectives. Journal of Operations Management, 21, $353-369$.

Juha, M. \& Pentti, J. (2008). Managing risks in organizational purchasing through adaptation of buying centre structure and the buying process. Journal of Purchasing \& Supply Management, 14, $253-262$.

Kathuria, R.; Joshi, M. P. \& Porth, S. J. (2007). Organizational alignment and performance: past, present and future. Management Decision, 45 (3), 503 - 517.

Ketokivi, M. \& Jokinen, M. (2006). Strategy, uncertainty and the focused factory in international process manufacturing. Journal of Operations Management, 24, 250 - 270.

Kim, J. S. \& Arnold, P. (1996). Operationalizing manufacturing strategy: an exploratory study of constructs and linkage. In- 
ternational Journal of Operations \& Production Management, 16 (12), $45-73$.

Kohli, A.K.; Jaworski, B. J. \& Kumar, A. (1993). MARKOR: a measure of market orientation, Journal of Marketing Research, 30 (4), $467-477$.

Kouvelis, P.; Chambers, C. \& Wang, H. (2006). Supply Chain Management Research and Production and Operations Management: review, trends and opportunities. Production and Operations Management, 15 (3), 449 - 469.

Lee, C. W.; Kwon, I. W. G. \& Severance, D. (2007). Relationship between supply chain performance and degree of linkage among supplier, internal integration and customer. Supply Chain Management: An International Journal, 12 (6), 444 - 452.

Loomba, A. P. S. (1998). Product distribution and service support strategy linkages: an empirical validation. International Journal of Physical Distribution E Logistics Management, 28 (2),143 -161 .

Luftman, J. (2000). Assessing Business-IT Alignment Maturity. Communications of the Association of Information Systems, 4 (14).

Malhotra, N. K. (2001). Pesquisa de Marketing: uma orientação aplicada. Brasil: Porto Alegre: Bookman, $3^{\mathrm{a}} \mathrm{ed}$.

McAdam, R. \& Bailie, B. (2002). Business performance measures and alignment impact on strategy: the role of business improvement models. International Journal of Operations \& Production Management, 22 (9), 972 - 996.

Mentzer, J. T.; Rutner, S. M. \& Matsuno, K. (1997). Application of the means-end value hierarchy model to understanding logistics service value. International Journal of Physical Distribution E Logistics Management, 27, (9/10), 630 - 643.

Miller, D. \& Friesen, P. H. (1986). Porter's (1980) generic strategies and performance: an empirical examination with American data. Part I: testing porter. Journal of Management Studies, $7,37-55$.

Morita, M. \& Flynn, E. J. (1997). The linkage among management systems, practices and behavior in successful manufacturing strategy. International Journal of Operations \& Production Management, 17 (10), 967 - 993.

Neely, A. (1993). Production/operations management: research process and content during the 1980's. International Journal of Operations \& Production Management, 13 (1), 5 - 18.

O'Regan, N. \& Ghobadian, A. (2005). Innovation in SMEs: the impact of strategic orientation and environmental perceptions. International Journal of Productivity and Performance Management, 54 (2), 81 - 97.

Pagh, J. D. \& Cooper, M. C. (1998). Supply Chain Postponement and Speculation Strategies: How to Choose the Right Strategy. Journal of Business Logistics, 19 (2), 13 - 33.

Papke-Shields, K. E. \& Malhotra, M. K. (2001). Assessing the impact of the manufacturing executive's role on business performance through strategic alignment. Journal of Operations Management, 19, 5- 22.

Parasuraman, A.; Zeithaml, V. A. \& Berry L.L. (1985). A conceptual model of services quality and its implication for future research. Journal of Marketing, 49 (4), 41-50.

Parker, G. G. \& Anderson Jr., E. (2002). From buyer to integrator: the transformation of the supply-chain manager in the vertically disintegrating firm. Production and Operations Management, 11 (1).

Paulraj, A.; Chen, I. J. \& Flynn, J. (2006). Levels of strategic purchasing: impact on supply integration and performance. Journal of Purchasing \& Supply Management, 12, 107 - 122.

Porter, M. E. (1989). Vantagem competitiva: criando e sustentando um desempenho superior. Brasil, Rio de Janeiro: Campus.

Porter, M. E. (1996). Estratégia Competitiva: técnicas para análise de indústrias e da concorrência. Brasil, Rio de Janeiro: Campus.

Prajogo, D. I. (2007). The relationship between competitive strategies and product quality. Industrial Management $\mathcal{E}$ Data Systems, 107 (1), $69-83$.

Pressey, A. D.; Winklhofer, H. M. \& Tzokas, N. X. (2009). Purchasing practices in small - to medium - sized enterprises: An examination of strategic purchasing adoption, supplier evaluation and supplier capabilities. Journal of Purchasing $\mathcal{E}$ Supply Management, 1 - 13 .

Rajagopalan, S. \& Yu, H. L.(2001). Capacity planning with congestion effects. European Journal of Operational Research, 134, $365-377$.

Richardson, P.R., Taylor, A. J. \& Gordon, J.R.M. (1985). A Strategic Approach to Evaluating Manufacturing Performance. Interfaces, 15 (6), $15-27$.

Ring, P. S. \& Vand De Ven, A. H. (1992). Structuring co-operative relationship between organizations. Strategic Management Journal, 11 (1), 483 - 498.

Rumelt, R. P. (1974). Strategy, Structure and Economic Performance. Harvard University Press, Cambridge, MA.

Sabherwal, R. \& Chan, Y. E. (2001). Alignment Between Business and IS Strategies: A Study of Prospectors, Analyzers and Defenders. Information Systems Research, 12 (1), 11 - 33.

Saura, I. G.; Francés, D. S.; Contrí, G, B. \& Blasco, M. F. (2008). Logistics service quality: a new way to loyalty. Industrial Management \& Data Systems, 108 (5), 650 - 668.

Scherpereel, C. M. (2006). Alignment: the duality of decision problems. Management Decision, 44 (9), 1258 - 1276.

Schroeder, R. G.; Scudder, G. D. \& Elm, D. R. (1989). Innovation in manufacturing. Journal of Operations Management, 8 (1), 1 - 15.

Skinner, W. (1969, may-june). Manufacturing - missing link in corporate strategy. Harvard Business Review, 136 - 145.

. (1974, may-june). The focused factory. Harvard Business Review.

Smaczny, T. (2001). Is an alignment between business and information technology the appropriate paradigm to manage IT in today's organizations? Management Decision, 39 (10), 797 - 802.

Spring, M. \& Boaden, R. (1997). One more time, how do you win orders: a critical reappraisal of the Hill's manufacturing 
strategy framework. International Journal of Operations \& Production Management, 17 (8), 757 - 779.

Stock, J. R. \& Lambert, D. M. (2001). Strategic Logistics Management. Fourth Edition. New York: McGraw Hill.

Sun, H. \& Hong, C. (2002). The alignment between manufacturing and business strategies: its influence on business performance. Technovation, 22, 699 - 705.

Sussland, W. A. (2003). Align your management processes for effectiveness. The TQM Magazine, 15 (2), 108 - 116.

Swift, C. O. (1995). Preferences for Single Sourcing and Supplier Selection Criteria. Journal of Business Research, 32, 105 - 111.

Tan, K. C.; Kannan, V. R. \& Handfield, R. B. (1998). Supply chain management: supplier performance and firm performance. International Journal of Purchasing and Materials Management, summer, 34 (3), 2 - 9.

Tucker, F. G. (1994). Creative Customer Service Management. International Journal of Physical Distribution \& Logistics Management, 24 (4), $32-40$.

Van Donk, D. P. \& Van der Vaart, T. (2007). Responsiveness through buyer-focused cells: exploring a new supply strat- egy. International Journal of Operations \& Production Management, 27 (12), $1362-1379$.

Vaart, T. V. \& Van Donk, D. P. (2006). Buyer-focused operations as a supply chain strategy: identifying the influence of business characteristics. International Journal of Operations $\mathcal{E}$ Production Management, 26 (1), 8 - 23.

Venkatraman, N. (1989). The Concept of Fit in Strategy Research: Toward Verbal and Statiscal Correspondence. Academy of Management Review, 14 (3), 423 - 444.

Venkatraman, N. \& Camillus, J. C. (1984). Exploring the concept of "fit" in strategic management. Academy of Management Review, 9 (3), $513-525$.

Wanke, P. (2004). Impactos da sofisticação logística de empresas industriais nas motivações para terceirização. Gestão $\mathcal{E}$ Produção, 11 (2), 1 - 20.

Ward, P. T.; Mccreery, J. K. \& Anand, G. (2007). Business strategies and manufacturing decisions: an empirical examination of linkages. International Journal of Operations \& Production Management, 27 (9), 951 - 973.

Wheelwright, S. C. (1984). Manufacturing Strategy: defining the missing link. Strategic Management Journal, 5 (1), 77 - 91.

\section{AUTHOR'S BIOGRAPHY}

Antonio Domingos Padula, Ph.D., Associate Professor of the School of Management/UFRGS-Federal University at Porto Alegre (Brazil). Mechanical Engineer (Brazil-1980), Docteur/PhD en Sciences de Gestion (Université des Sciences Sociales de Grenoble - France-1990). Professor of Production and Operations Management. Research areas: Industrial Organization and Global Value-Chains. Research subjects: Brazilian bioenergy supply-chains, Agri-food supply-chains. More than 70 papers presented/published in national and international congresses and journals. Supervised 10 doctoral dissertations and 40 master in science theses (Management). Senior coordinator of various research projects financed by national and international agencies.

Margareth Rodrigues de Carvalho Borella, Doctor, Professor of the University of Caxias do Sul at Caxias do Sul (Brazil). Chemical Engineer (Brazil-1985), Doctor in Management by School of Management/UFRGSFederal University at Porto Alegre (Brazil-2009). Professor of Production and Operations Management. Research areas: Production and Operations Strategy and Supply Chain Management. Research subjects: Hybrid Organization, Environmental Sustentability and Supply Chain. Approximately 30 papers presented/published in national and international congress, journals and books. Supervised more than 100 graduate and postgraduate monographs (Management and Production Engineering). 